\title{
Pembinaan Mahasiswa Mengantisipasi Krisis Identitas Diri di STT Real Batam
}

\author{
Fredy Simanjuntak ${ }^{1 *}$, Delfi², David Martinus Gulo ${ }^{3}$, Messy Causa Primay ${ }^{4}$, Yosepin \\ Koreanti Hutabarat ${ }^{5}$, Debora Agustina Ratu.P6 \\ 1, 2, 3, 4, 5, 6 Prodi Teologi, STT REAL Batam \\ *fredygrace@gmail.com
}

\begin{abstract}
Self-identity in a Christian perspective is very vital, especially in student life. A good self-identity is a process that is continuously formed through correct self-understanding. Individuals who do not have a good understanding of themselves will have the potential to experience an identity crisis which leads to being unable to accept themselves, difficult to realize the advantages and disadvantages that exist in themselves. Students are often a group that is quite vulnerable to experiencing a character crisis caused by a mistaken recognition of self-identity. This journal was compiled using descriptive qualitative methods. This paper aims to provide moral and psychological encouragement through fostering students so that they can understand their identity as followers of Christ. The results of this activity can be felt by students of STT Real batam reaching 75\%. This can be seen in the activities and behavior of students both in the campus environment, dormitories and churches where they minister.
\end{abstract}

Keywords: Coaching, Students, Crisis, Self-Identity, STT Real Batam

\begin{abstract}
Abstrak
Identitas diri dalam perspektif kekristenan sangatlah vital, terutama pada kehidupan mahasiswa. Identitas diri yang baik adalah proses yang dibentuk terus melalui pemahaman diri yang benar. Individu yang tidak memiliki pemahaman yang baik mengenai dirinya, akan berpotensi mengalami krisis identitas yang berujung pada tidak mampu menerima diri sendiri, sulit menyadari keunggulan maupun kekurangan yang ada pada dirinya. Mahasiswa kerap menjadi kelompok yang cukup rentan mengalami krisis karakter yang disebabkan oleh pengenalan yang keliru akan identitas diri. Penelitian ini disusun dengan menggunakan metode kualitatif deskriptif. Paper ini bertujuan untuk memberi dorongan secara moral dan psikologi lewat pembinaan mahasiswa supaya dapat memahami identitas dirinya sebagai pengikut Kristus. Hasil dari kegiatan ini dapat dirasakan oleh mahasiswa STT Real batam mencapai 75\%. Hal ini nampak pada aktifitas dan perilaku mahasiswa baik di lingkungan kampus, asrama maupun gereja di mana mereka melayani.
\end{abstract}

Kata kunci: Pembinaan, Mahasiswa, Krisis, Identitas Diri, STT Real Batam

\section{PENDAHULUAN}

Media Kerap kali memberitakan berbagai peristiwa amoral/asusila dan kriminal saat ini melibatkan para mahasiswa. Potret sikap criminal mahasiswa banyak terdengar apakah itu didunia nyata maupun di dunia maya. Peristiwa-peristiwa tawuran ataupun perkelahian yang memakan korban kekerasan,seks bebas, aborsi, pelecehan seksual, pencurian dan masih banyak lagi. Tingkat kejahatan seperti yang di sebutkan di atas ternyata semakin canggih didukung oleh majunya dan berkembangnya teknologi. Hal ini merupakan satu persoalan besar yang dapat dilihat dalam kehidupan para mahasiswa.

Selain persoalan mengenai masa depan, hal yang paling banyak menyita perhatian para mahasiswa muda adalah problematika identitas diri yang masih belum kunjung dewasa. Pandangan yang keliru akan identitas diri tentunya menjadi masalah yang terpendam seperti bom waktu yang sewaktu-waktu dapat merugikan entah itu diri pribadi mahasiswa ataupun orang lain.

Penting untuk diketahui bahwa dalam pembentukan identitas ini adalah akal budi, yang daripadanya terbentuk system kepercayaan yang juga dipengaruhi oleh pengalaman yang pada 
akhirnya membentuk paradigma. ${ }^{1}$ Semntara karakter berkaitan dengan akhlak atau budi pekerti, yang merupakan hasil perpaduan antara pikiran dan perasaan. Hal itu berarti bahwa apa yang diekspresikan oleh seseorang melalui sikap atau perilakunya merupakan hasil dari apa yang dipahami atau dipikirkannya. Cara seseorang memahami atau memandang identitas dirinya akan mempengaruhi karakternya. Jika ia memahami identitas dirinya dengan benar, maka besar kemungkinan ia akan menampilkan karakter yang baik pula. Begitu juga sebaliknya, jika seseorang tidak memahami identitas dirinya dengan benar, maka hal itu dapat mengakibatkan kemunduran atau penyimpangan karakter.

Demikian pula perilaku yang yang ditampilkan seorang mahasiswa, dalam hal ini mahasiswa STT Real Batam, merupakan hasil refleksi dari pemahaman identitas dirinya sebagai pengikut Kristus. Jika ia memahami identitas dirinya di dalam Kristus dengan benar, maka ia akan menjadi pribadi yang berkualitas, sebagaimana Kristus nejadi teladan yang berkualitas bukan hanya sekedar pencitraan diri, namun menunjukkan sebuah pemikiran dalam mehahami identitas diri yang utuh.

Penulis ingin melihat beberapa hal yang dirumuskan melalui pertanyaan berikut: Bagaimana Realitas Pembinaan Mahasiswa Mengantisipasi Krisis Identitas Diri di STT Real Batam? Beranjak dari rumusan masalah, penelitian ini bertujuan untuk memberi dorongan secara moral dan psikologi lewat pembinaan mahasiswa supaya dapat memahami identitas dirinya sebagai pengikut Kristus.

\section{METODE}

Jurnal ini disusun dengan menggunakan metode kualitatif deskriptif), dengan memusatkan pergatian pada masalah-masalah yang bersifat actual. Adapun ciri metode deskriptif adalah memusatkan perhatian pada masalah-masalah yang ada pada saat penelitian dilakukan atau masalahmasalah yang bersifat aktual; menggambarkan fakta-fakta tentang masalah yang diselidiki sebagaimana adanya, diiringi interpretasi rasional yang memadai (adequate). ${ }^{2}$ Alwasilah menjelaskan bahwa teknik deskriptif lazim dipakai untuk mengukur tiga hal; (1) eksistensi dan distribusi berbagai tingkah laku atau karakteristik yang terjadi secara alami; (2) frekwensi kemunculan kejadian yang terjadi secara alami; (3) hubungan yang mungkin ada antara karakteristik, tingkah laku, kejadian, atau fenomena yang menjadi perhatian peneliti. ${ }^{3}$

Dalam memahami masalah penelitian ini, peneliti melakukan kegiatan penelitian dengan mengamati langsung di lapangan (field research) sekaligus menjadikan diri sebagai instrumen utama dalam mengumpulkan dan menginterpretasikan data. MetodeBerdasarkan informasi dan kejadian di lapangan maka tim membuat suatu kegiatan sebagai sasaran. Sasaran pelaksanaan kegiatan ini adalah mahasiswa STT Real Batam yang ada di 4 asrama STT Real Batam. Dukungan dan kepedulian yang diberikan oleh para dosen dan kepala asrama Sekolah Tinggi Teologi Real Batam dapat memberikan dampak positif.

Pembinaan ini sangat bermanfaat bagi para mahasiswa yang tinggal di lingkungan asrama STT Real Batam sebagaimana hasil dan penjelasan dalam artikel ini. Pendampingan ini dilaksanakan pada tanggal 7 Januari 2019- 14 Juni 2019 di kota Batam. Sedangkan pendekatan yang dilakukan adalah dengan 'pendekatan sosiologis' yaitu semua tindakan sosial melalui pranata (lembaga, institusi) asrama, pendidikan dan keagamaan, yang berperan dalam proses pengenalan jati diri mahasiswa untuk menjadi orang yang lebih baik. Untuk mencapai hal tersebut, diperlukan pengamatan kritis yang dilandasi pemahaman terhadap seluruh kegiatan dalam menggali informasi yang jelas mengenai proses berjalannya kegiatan, pemanfaatan komponen yang ada dan perilaku mahasiswa. Dari pengamatan

\footnotetext{
${ }^{1}$ Rhonda Byrne, The Secret (Jakarta: Gramedia, 2007).17

${ }^{2}$ H. Hadari Nawawi, Metode Penelitian Bidang Sosial, 5th ed. (Yogyakarta: Gadjah Mada University Press, 1991).64

${ }^{3}$ Alwasilah, Pokoknya Kualitatif: Dasar-Dasar Merancang Dan Melakukan Penelitian Kualitatif (Jakarta: Dunia Pustaka Jaya, 2008).151
} 
yang dalam dan analisis yang tajam, diharapkan peneliti dapat membuat suatu model pembinaan identitas diri yang tepat, sesuai dengan yang dibutuhkan oleh seluruh komponen yang ada di Sekolah Tinggi Teologi Real Batam.Berdasarkan data yang telah didapat maka setiap semester dikeluarkan SK Pembimbingan bagi Para dosen untuk melaksanakn pembinaan secara berkelompok sesuas dengan group masing-masing baik dalam bentuk sharing, diskusi, berbagi testimoni dan lainnya.

\section{HASIL DAN PEMBAHASAN \\ Pembinaan Personal \& Kekeluargaan}

\section{Family Gathering}

Salah satu cara yang ditempuh oleh para dosen dalam pembinaan mahasiswa adalah pembinaan dengan system pendekatan secara personal, Dikarenakan rasa kekeluargaan akan muncul sehingga mahasiswa akan merasakan penghargaan diri. Secara umum pembinaan yang dilaksanakan pada mahasiswa STT Real Batam mengarah pada system kekeluargaan tanpa mengadopsi beberapa orang mahasiswa dalam status keluarga binaan. Pembinaan pada umumnya dilakukan secara berkala setiap minggunya di akhir pekan.

Karakter personal berhubungan dengan manusia secara pribadi, bersifat perseorangan. Setiap orang memiliki hakekat kemanusiaannya sebagai seorang individu yang diciptakan Allah secara unik dan istimewa, yang diekspresikan melalui sikap dan perilaku pribadi untuk mewujudkan eksistensinya di antara individu lainnya. Karakter individual mahasiswa menunjukkan jati dirinya dan membentuk kualitas kehidupannya. Karakter individual tersebut tampak melalui: kemampuan seseorang dalam memahami realitas diri baik secara fisik maupun psikis dan mampu menentukan sikap yang tepat dan benar untuk diri sendiri, ${ }^{4}$ kemampuan untuk mengaktualisasikan dirinya, memiliki keyakinan/optimisme akan kemampuan dirinya, kemandirian untuk berinisiatif dan berkreativitas, serta berusaha mencapai cita-cita dan tujuan hidup dengan visi misi yang benar (Ams. 6:6, Mat. 25:29), Memiliki sikap positif merupakan buah dari iman percaya remaja kepada Allah dimana ia menghayati dan melaksanakan firman Allah, yaitu meneladani sifat dan sikap positif yang diteladankan oleh Kristus kepadanya (Yak. 1:22; 2:17, 22, 24, 26).

Problematika yang terjadi pada mahasiswa dapat disebabkan oleh tidak terpenuhinya kebutuhan psikologis dasarnya dengan baik terkadang dapat menyebabkan kebingungan terhadap kedudukannya dan kesulitan untuk menentukan sikapnya sehingga mengarahkan pada perilaku yang tidak wajar. Konflik dalam diri seseorang umumnya berakar dari konflik dan krisis identitas yang terjadi di dalam dirinya.

Adapun beberapa kegiatan pembinaan bersifat non formal dalam bentuk family gathering di STT Real Batam. Program Family Gathering yang biasanya dikonsep sebulan sekali oleh pihak dosen pembina, berisi kegiatan permainan individual maupun kelompok, makan bersama.

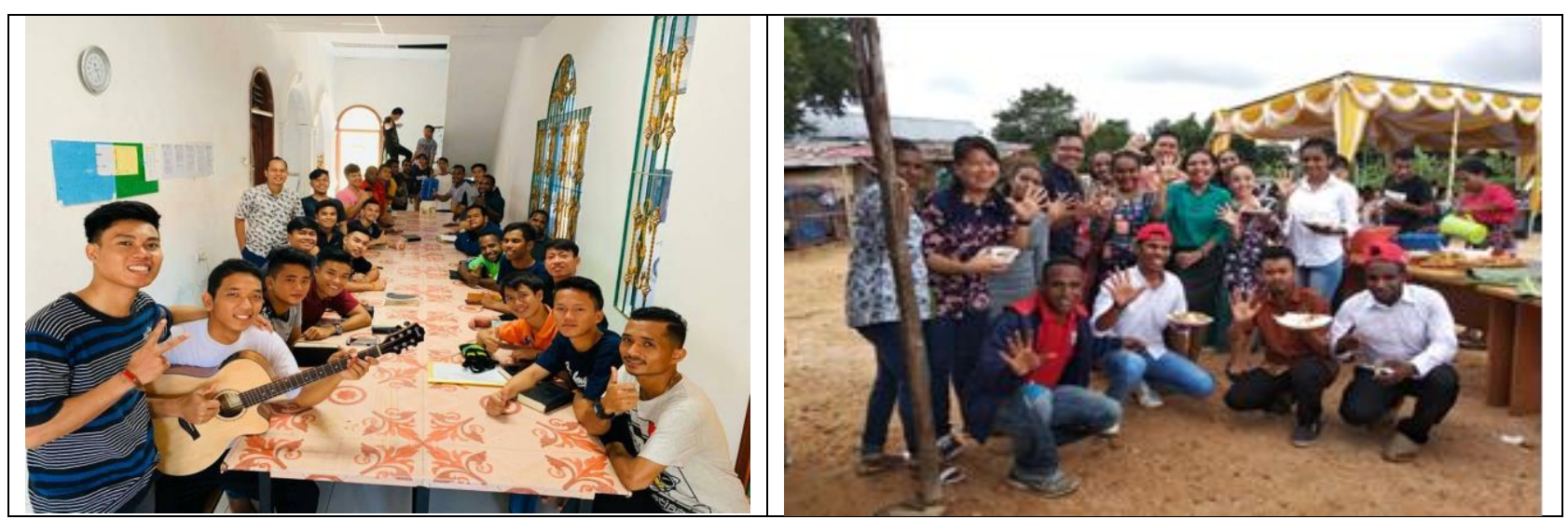

Gambar 1. Foto Pembinaan Melalui Family Gathering

${ }^{4}$ Antonius Atosokhi Gea, Antonina Panca Yuni, and Yohanes Babar Wulandari, Relasi Dengan Diri Sendiri (Jakarta: Elex Media Komputindo, 2002).7 
Berdasarkan Gambar 1 dapat memberi informasi bahwa Kegiatan Family Gathering menjadi momentum yang sangat tepat untuk memberikan Quality Family Time bagi para mahasiswa untuk berkumpul dari berbagai prodi, semester dan asrama. Mengingat sebagian besar waktu mereka telah dihabiskan mahasiswa di kampus, gereja dan asrama masing-masing dan sangat sedikit waktu mereka berkumpul secara keseluruhan. Sehingga dengan kegiatan Family Gathering, para mahasiswa dapat merasakan suasana liburan yang menyenangkan bersama dosen, para staff dan teman-teman sesama mahasiswa STT Real Batam.

Hal ini sangat penting, karena kegiatan ini bermanfaat untuk membangun ikatan emosional kekeluargaan antara para dosen dan mahasiswa serta menguatkan kecintaan terhadap institusi, maka hal tersebut akan berdampak pada meningkatnya semangat belajar dan mendidik para mahasiswa dan dosen. Karena dosen telah mengambil peran sebagai keluarga dekat mahasiswa selama dalam proses belajar telah memberikan dukungan moril yang sangat kuat untuk mahasiswa konsisten menyelesaikan proses studinya di STT Real Batam.

\section{Character Buillding}

Dosen harus dapat menjadi supporting sistem yang mendukung mahasiswa untuk menemukan jati dirinya. Berbagai macam program harus diintegrasikan baik secara akademis, social, kekeluargaan untuk merangsang jiwa kreatif dan kepemimpinan bagi mahasiswa. Salah satu indikator keberhasilan pendidikan tinggi dapat dilihat dari kemampuan mahasiswa untuk memiliki kepribadian yang mandiri. Selain kehidupan pribadi yang jauh lebih berkembang mahasiswa pun secara umum cenderung menempatkan diri dalam pergaulan yang mendukung dan positif. Itulah sebabnya sebagai salah satu elemen terpenting dalam Perguruan Tinggi, dosen wajib hadir dalam kehidupan pribadi dan social mahasiswa bimbingannya sebagai support system.

Dosen Pembina adalah figur orang tua yang penting sebagai supporting system mahasiswa di lingkungan kampus. Kehidupan pribadi dan kehidupan spiritual dosen tentunya memberikan pengaruh penting bagi pembinaan mahasiswa dalam menghidupi kebenaran Allah yang paling relevan di masa studi. Pengenalan dan hubungan manusia dengan Allah juga terbentuk melalui pemahaman akan firman Allah melalui norma agama atau keyakinan yang dianut tersebut. Mahasiswa akan menampilkan sikap dan perilakunya berdasarkan pemahamannya tentang ajaran iman Kristen yang dianutnya. Oleh karena itu, ia harus memahami ajaran/kehendak Allah dengan benar agar ia mampu bersikap dan berperilaku dengan benar pula. ${ }^{5}$

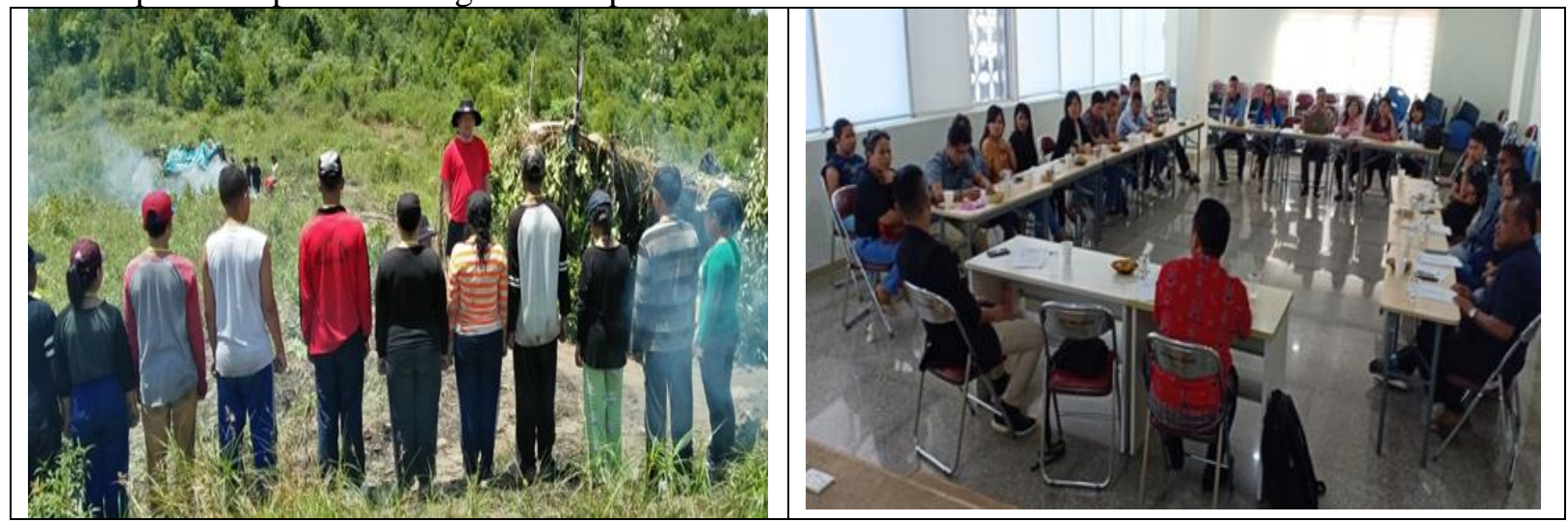

Gambar 2. Foto Pembinaan Melalui Character Building

Berdasarkan Gambar 2 dapat memberi informasi bahwa kegiatan character Building merupakan program pembinaan yang dilakukan oleh Dosen kepada mahasiswa setiap semester. Tujuan dari kegiatan ini adalah untuk pembentukan karakter mahasiswa. Karakter tidak bisa diwariskan, karakter tidak bisa dibeli dan karakter tidak bisa ditukar, karakter harus dibangun dan dikembangkan secara sadar hari demi hari melalui suatu proses, tidak instan. Karakter bukanlah sesuatu bawaan sejak lahir yang tidak dapat diubah lagi seperti sidik jari. Pembinaan ini merupakan

${ }^{5}$ Zinzendorf Dachi, "Prinsip Kepemimpinan Orang Tua Dalam Keluarga Menurut Ulangan 11: 18-21," KAIROS: Jurnal Teologi Lutheran 1, no. 1 (2018): 31-46. 
sebuah proses untuk membentuk, menumbuhkan, mengembangkan dan mendewasakan kepribadian mahasiswa agar menjadi pribadi yang bijaksana dan bertanggung jawab melalui pembiasaan pikiran, hati dan tindakan secara berkesinambungan yang diasosiasikan kepada pemimpin, Pembina, sesama mahasiswa dan lingkungan.

Melalui kegiatan ini mahasiswa mendapat didikan dan mandate budaya yang bertanggung jawab terhadap Tuhan. Mahasiswa dibekali pengetahuan alam untuk menjaga kelangsungan hidup manusia dan kelestarian lingkungannya. Hubungan manusia dengan alam sama halnya seperti hubungan manusia dengan Allah, sebagaimana dikatakan oleh Drummond bahwa dunia ini adalah tubuh Allah - sebagai bentuk transformasi dari gambar Allah sehingga kita terkait dengan alam. ${ }^{6}$ Dalam usaha menjaga kelangsungan hidupnya, manusia selalu berhubungan dengan lingkungannya yaitu dengan usaha memanfaatkan sumber daya alam dengan disertai pengelolaan yang baik, terutama terhadap sumber daya alam yang tidak dapat diperbaharui supaya tidak cepat habis. Pembinaan ini sekaligus menjadi ikon pembinaan di STT Real Batam untuk mengembangkan sumber daya manusia mahasiswa, di mana sumber daya manusia yang dimaksud di sini berfungsi sebagai pengelola dan berkewajiban melestarikan lingkungannya. Salah satu cara dalam pembinaan sumber daya manusia hubungannya dengan pelestarian sumber daya alam aclalah melalui pendidikan, yaitu character building.

\section{Tantangan dalam Pembinaan Mahasiswa Komunikasi}

Dosen harus beradaptasi untuk menciptakan proses komunikasi yang kondusif bagi para mahasiswa bimbingannya. Dalam penjelasannya Effendy menyatakan, pendidikan adalah komunikasi, dalam proses tersebut terlibat dua komponen yang terdiri atas manusia, yakni pengajar sebagai komunikator dan pelajar sebagai komunikan. ${ }^{7}$ Prinsip pengenalan sangat penting dalam proses komunikasi, pengenalan tentunya kunci kedekatan antar individu. Dalam komunikasi dosen penting untuk mengalokasikan waktu untuk berkenalan dengan mahasiswa bimbingannya satu per satu. Dosen perlu mengenal lebih dekat pribadi mahasiswa, latar belakang, hobi, dan kehidupan keluarga mahasiswa.

Tentu membutuhkan waktu yang tidak sedikit untuk membangun konektivitas khususnya dengan mahasiswa baru. Proses seperti ini adalah merupakan salah satu bentuk investasi social yang berharga di kemudian hari. Jika pola komunikasi termediasi seperti ini akan berlangsung lama. Dengan sedikit demi sedikit dosen Pembina akan memiliki pengenalan yang penting dalam kehidupan mahasiswa sendiri. Ini merupakan bekal berharga dalam relasi pembinaan.

Dosen pembimbing memegang peranan penting dalam preoses identifikasi ini, karena mereka dapat membantu anak muda dengan menjelaskan secara lebih mendalam mengenai peranan agama dalam kehidupan mahasiswa sehingga penyadaran ini memberikan arti yang baru pada hal spiritual yang telah diperolehnya. Yang paling penting adalah pengenalan dosen pembina, sebelum mereka mengharapkan mahasiswa mengenal dirinya. Dengan kata lain, apa yang diharapkan dari mahasiswa harus dapat dilaksanakan terlebih dahulu oleh orang tua dan dosen, seperti beribadah dan mengunjungi tempat ibadah sesuai dengan iman kepercayaannya. ${ }^{8}$ Mahasiswa pun memerlukan bentuk penghargaan positif, oleh karena ini Pembina penting untuk peka memperlakukan tiap siswa sesuai keunikan masing-masing. Dosen perlu belajar menghargai keunikan mahasiswa dengan tidak menyamaratakan tuntutan.

\section{Pembentukan identitas diri Mahasiswa}

Para pendidik di kampus, khususnya dosen hendaknya selalu terpacu untuk memperbaharui materi maupun pola pengajarannya dengan mementingkan pengajaran tentang identitas diri di dalam Kristus maupun tentang karakter Kristen. Hal itu dapat disinergikan dalam penyusunan program pengajaran maupun dalam proses pembelajaran melalui berbagai metode yang kreatif serta melalui

\footnotetext{
${ }^{6}$ Celia Deanne-Drummond, Teologi Dan Ekologi (Jakarta: BPK Guniung Mulia, 2011).154

${ }^{7}$ Onong Uchjana Effendy, Ilmu Komunikasi Teori Dan Praktik (Bandung: Remaja Rosdakarya, 2005).60

${ }^{8}$ Kartini Kartono, Patologi Sosial II Kenakalan Remaja (Jakarta: Rajawali, 1992).
} 
keteladanan hidup yang mencerminkan pemahaman akan identitas diri di dalam Kristus yang tercermin lewat karakter Kristen yang berkualitas.

STT Real juga bekerja sama dengan puluhan gereja interdoneminasi di kota Batam dalam program praktek pelayanan mahasiswa, hal ini juga memberikan ruang yang luas bagi mahasiswa untuk dibentuk secara mandiri di bawah bimbingan pendeta atau pemimpin gereja yang membimbingnya untuk semakin memahami identitas dirinya di dalam Kristus. Hal itu terintegrasikan antara lain melalui kegiatan ibadah, persekutuan pemuda, penelaahan Alkitab, kamp pemuda, retreat, karya wisata, keterlibatan mahasiswa dalam berbagai pelayanan sosial di masyarakat, dan sebagainya.

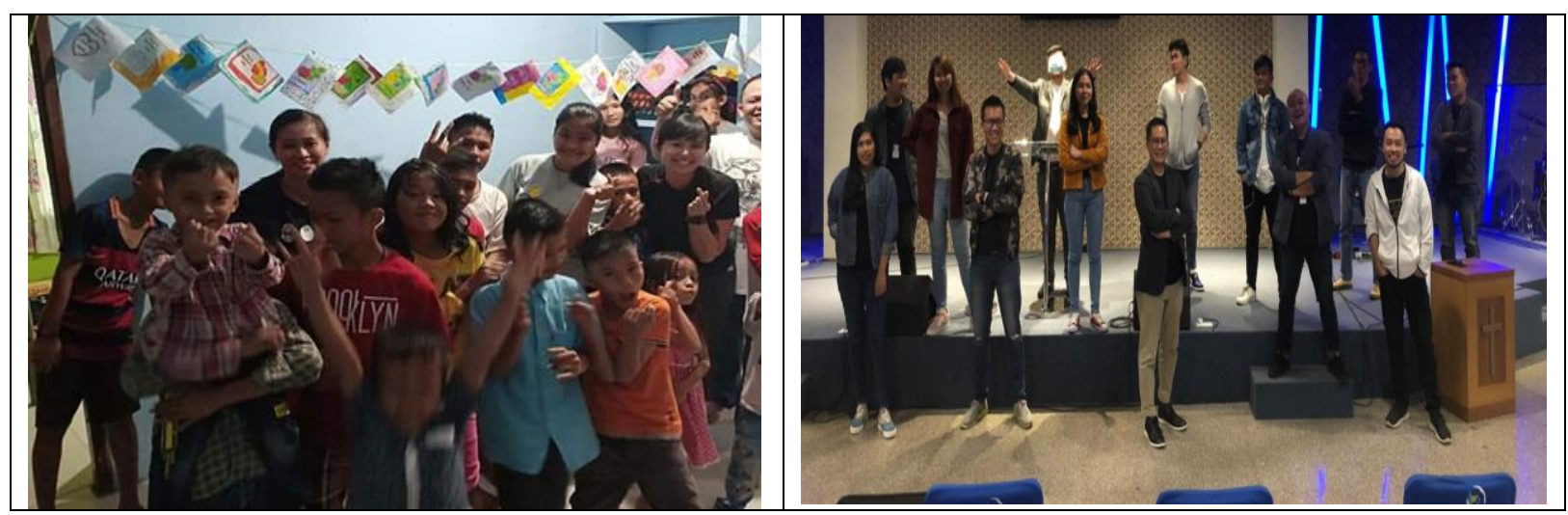

Gambar 3. Foto Keterlibatan Mahasiswa Dalam Pelayanan Gerejawi

Berdasarkan Gambar 3 dapat memberi informasi bahwa kegiatan praktek pelayanan mahasiswa sangat produktif dalam menumbuhkan kedewasaan iman bagi para mahasiswa untuk mengimplementasikan iman uang mereka hidupi di dalam Kristus dalam pelayanan sebagaimana Groome menyatakan, "Iman sebagai kegiatan percaya (faith as believing) yaitu berkeyakinan teguh pada kepercayaan Kristen yang esensial; Iman sebagai kegiatan mempercayakan (faith as trusting) yaitu berhubungan secara pribadi dengan Allah yang diekpresikan dalam kesetiaan, kasih dan kelekatan; Iman sebagai kegiatan melakukan (faith as doing) yaitu menanggapi kasih Allah dengan mengasihi Allah dan sesama seperti mengasihi diri sendiri. ${ }^{9}$

\section{SIMPULAN}

Kegiatan pembinaan di STT Real Batam telah berjalan dengan baik sesuai dengan tujuan dari pengabdian masyarakat. Hasil kegiatan dari pengabdian masyarakat ini telah memberikan dampak yang positif, yakni proses pengenalan terhadap diri sendiri bagi mahasiswa meliputi pengakuan, penerimaan, dan penghargaan pada diri sendiri secara keseluruhan. Dari hasil pembahsa di atas maka dapat disimpulkan, 1) Melalui pengenalan diri, mahasiswa dapat mengembangkan dan menempatkan dirinya dalam setiap situasi kehidupan, 2) Mahasiswa bersikap positif baik terhadap dirinya sendiri maupun lingkungannya, berarti memiliki kepercayaan diri yang tinggi dan merasa bahwa hidupnya bermakna sehingga ia mampu mengembangkan potensinya untuk meraih kesuksesan dalam hidupnya, 3) Mahasisw dapat hidup rukun berdampingan dengan sesame mahasiswa lain yang majemuk melalui hubungan komunikasi dan kerja sama yang baik, mendahulukan kepentingan bersama, berorientasi untuk selalu melayani orang lain, menolong sesama yang membutuhkan tanpa membeda-bedakan, serta mengupayakan keadilan dan kesejahteraan kehidupan dengan seluruh ciptaan Allah. Untuk itu, remaja juga membutuhkan pertolongan dan bimbingan, khususnya dari para dosen baik untuk dalam mendukung kehidupan mahasiswa secara fisik, psikis maupun secara spiritual. Dengan pembinaan yang dilakukan oleh para dosen seperti ini dapat membekali mahasiswa dengan pengetahuan, penerimaan, pola pikir, pengharapan sehingga mahasiswa dapat mengalami krisis identitas dalam dirinya.

${ }^{9}$ Thomas Groome, Christian Religion Education (Jakarta: BPK Guniung Mulia, 2011).81-94 


\section{DAFTAR PUSTAKA}

Alwasilah. Pokoknya Kualitatif: Dasar-Dasar Merancang Dan Melakukan Penelitian Kualitatif.

Jakarta: Dunia Pustaka Jaya, 2008.

Byrne, Rhonda. The Secret. Jakarta: Gramedia, 2007.

Dachi, Zinzendorf. "Prinsip Kepemimpinan Orang Tua Dalam Keluarga Menurut Ulangan 11: 18-21."

KAIROS: Jurnal Teologi Lutheran 1, no. 1 (2018): 31-46.

Deanne-Drummond, Celia. Teologi Dan Ekologi. Jakarta: BPK Guniung Mulia, 2011.

Effendy, Onong Uchjana. Ilmu Komunikasi Teori Dan Praktik. Bandung: Remaja Rosdakarya, 2005.

Gea, Antonius Atosokhi, Antonina Panca Yuni, and Yohanes Babar Wulandari. Relasi Dengan Diri Sendiri. Jakarta: Elex Media Komputindo, 2002.

Groome, Thomas. Christian Religion Education. Jakarta: BPK Guniung Mulia, 2011.

Kartono, Kartini. Patologi Sosial II Kenakalan Remaja. Jakarta: Rajawali, 1992.

Nawawi, H. Hadari. Metode Penelitian Bidang Sosial. 5th ed. Yogyakarta: Gadjah Mada University Press, 1991. 